\title{
Evaluation of the Different Antiphospholipid Antibodies for the Diagnosis of Antiphospholipid Syndrome
}

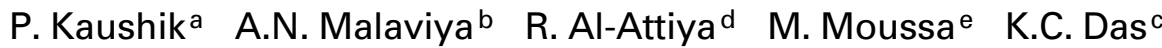 \\ a Medicine (Rheumatology), Mubarak Al-Kabeer Hospital, bDepartment of Medicine and \\ 'Haematology, Department of Pathology, Faculty of Medicine, Kuwait University, and \\ Mubarak Al-Kabeer Hospital, dClinical Immunology, Department of Microbiology, and \\ eDepartment of Community Medicine, Faculty of Medicine, Kuwait University, Kuwait
}

\section{Key Words}

Antiphospholipid antibody syndrome .

Anticardiolipin antibodies .

Anti- $\beta_{2}$-glycoprotein 1 antibodies $\cdot$ Hughes syndrome $\cdot$ Laboratory evaluation

\begin{abstract}
Objective: Antiphospholipid syndrome (APS) or Hughes syndrome is a frequently seen condition in Kuwait that is characterised by the presence of significant titres of a variety of antiphospholipid antibodies (aPL). The main clinical features of this syndrome include thrombosis (both venous and arterial), recurrent fetal wastage and thrombocytopenia. The aim of the present study was to find out the antibodies with a high predictive value for the diagnosis of APS. Methodology: The study included a total of 38 subjects. Nine of them were patients with proven primary APS, 10 with secondary APS and 19
\end{abstract}

were patients (controls) with weak clinical evidence of APS. After a complete clinical examination and routine investigations, the following categories of aPL were estimated by standard laboratory techniques: anticardiolipin antibodies of $\lg G$ and $\lg M$ isotypes (GPL and MPL, respectively), anti- $\beta_{2}$-glycoprotein-I antibodies (anti- $\beta_{2}$-GPI) of IgG and $\operatorname{lgM}$ isotypes and activated partial thromboplastin time as a surrogate for lupus anticoagulant (LAC). The tests were considered positive if the titres were more than a standard cut-off value provided by the manufacturer of the kits, and in one instance, the normal range was established in our laboratory (LAC). Results: The highest sensitivity $(78.9 \%)$ and diagnostic accuracy $(71.1 \%)$ were obtained by the estimation of GPL. However, excellent specificity $(100 \%)$ and positive predictive value $(100 \%)$ with almost as good a diagnostic accuracy (68.4\%) were also obtained with anti- $\beta_{2}$-GPI of IgG isotype.

\begin{tabular}{ll}
\hline KARGER & ( 1999 S. Karger AG, Basel \\
Fax +41 61 306 1234 34 & \\
$\begin{array}{l}\text { E-Mail karger@karger.ch } \\
\text { www.karger.com }\end{array}$ & $\begin{array}{l}\text { Accessible online at: } \\
\text { www.karger.com/journals/mpp }\end{array}$
\end{tabular}

Prof. A.N. Malaviya

Department of Medicine, Faculty of Medicine

PO Box 24923, Safat 1311 (Kuwait)

Tel. +965 5319596, Fax +965 5338907

E-Mail anand@hsc.kuniv.edu.kw 
All the other tests performed poorly when compared with these two. There was no difference in the performance of these tests between primary and secondary APS. Conclusion: Of the various aPL estimated, GPL and anti- $\beta_{2}$-GPI of IgG isotype were statistically sensitive and specific investigations for confirming the diagnosis of APS.

Copyright @ 1999 S. Karger AG, Basel

\section{Introduction}

Since its original description by Hughes in 1983 as a syndrome of thrombosis, recurrent fetal loss and thrombocytopenia associated with antibodies reactive with anionic phospholipids [1], this syndrome is now purported to be the commonest acquired hypercoagulable state [2]. The condition has been labelled 'antiphospholipid antibody sydrome' (APS) [3]. However, because of the recent discovery that antibodies seen in this syndrome may primarily be reactive against several cofactors (proteins) that are naturally associated with anionic phospholipids in the body, the term APS may be inappropriate. Therefore, to overcome the nomenclature problems and to give credit to the worker who first described the syndrome, a strong case has been made to use the eponym 'Hughes syndrome' for this condition $[4,5]$.

An earlier study from this institution had reported that Hughes syndrome was a commonly seen condition in hospitals in Kuwait [6]. Since then, clinical colleagues have frequently approached the rheumatology service for guidance in requisitioning appropriate laboratory investigations for the confirmation of diagnosis of APS and interpretation of their results.

The specific laboratory investigation that has been an integral part of the definition of this syndrome is the presence and persistence of significant titres of antiphospholipid antibodies (aPL) [7, 8]. However, aPL are a heterogeneous 'family' of auto-antibodies reactive against different anionic phospholipids and certain additional cofactors that are essential factors in prothrombin activation and other sequences in the cascade of blood coagulation [9]. The wide spectrum of clinical events and the heterogeneous nature of the aPL, therefore, confound the diagnosis of APS [10]. In this regard one of the more perplexing issues is that many infections, certain drugs and other underlying illnesses such as liver disease, malignancy and other acute-phase reactions may also be associated with elevated levels of aPL $[2,7]$. However, unlike the aPL associated with systemic lupus erythematosus (SLE) or other auto-immune diseases, infection and drug-associated aPL are usually not associated with clinical features of APS $[2,10]$. Thus there remains no uniform laboratory test to identify pathogenic aPL that have clinical relevance [10].

A variety of tests are available for the screening of aPL [11]. These include (i) anticardiolipin antibodies (aCL) and their immunoglobulin isotypes [IgG, IgM (GPL and MPL) and IgA]; (ii) assays for 'lupus anticoagulant' (LAC), and (iii) anti- $\beta_{2}$-glycoprotein I antibodies (anti- $\beta_{2}$-GPI) and their immunoglobulin isotypes [11]. The obvious question with regard to these antibodies is to identify the clinically relevant antibody/antibodies that correlate(s) best with the clinical features of APS $[2,10]$. Therefore, in the present study assays for several of these antibodies were carried out in clinically definite cases with primary or secondary APS and the results were compared with those in 'controls' with weak clinical evidence of APS. The objective of the study was to find the test(s) with high diagnostic accuracy for the diagnosis of APS. 


\section{Patients and Methods}

Patient Selection

For this study the following categories of patients were selected from the rheumatology service of the Mubarak Al-Kabeer Hospital, one of the two main teaching hospitals of this institution:

(1) patients with proven diagnosis of primary APS or clinical features highly suggestive of primary APS [7, $8,12]$; this group included 9 patients; (2) patients with a proven diagnosis of SLE: (a) who could be classified as cases of APS with SLE [13]; there were 10 such patients; (b) who were without any clinical evidence of APS; there were 7 such patients; (3) patients with clinical features that are not typical of, but occasionally reported in APS (clinical features that may or may not be a manifestation of this syndrome); there were 12 such patients.

The minimal diagnostic criteria for the diagnosis of APS were as follows [14]: clinical characteristics: venous thrombosis, arterial thrombosis, recurrent fetal loss, thrombocytopenia; laboratory characteristics: IgG aCL (moderate/high levels), IgM aCL (moderate/ high levels), positive LAC test. Conditions: patients with the syndrome should have at least 1 clinical +1 laboratory finding during their disease. The aPL test must be positive on at least 2 occasions more than 3 months apart.

\section{Data Collection}

Serum samples were collected over a period of 8 months. All the follow-up patients who attended the rheumatology service and new patients who could be categorised in any of the above 3 categories were selected for this study. Sera were separated on the day of the blood collection and frozen at $-70^{\circ} \mathrm{C}$ till tested (maximum storage time 6 months). Information on the clinical characteristics of the patients, reports of their routine investigations including complete blood counts, serum biochemistry, coagulation profile and specialised investigations that were required to confirm certain features of APS (e.g. duplex Doppler study and/or venography for deep-vein thrombosis, ventilation-perfusion scan for the diagnosis of pulmonary embolism, computed tomography and/or magnetic resonance imaging studies for neurological lesions) were collected.

The following categories of aPL were investigated: (1) aCL: GPL and MPL; (2) anti- $\beta_{2}$-GPI of IgG and IgM isotypes; (3) for the screening of LAC, kaolin clotting time or activated partial thromboplastin time and diluted Russell viper venom time.

Antiphospholipid Antibodies in Hughes Syndrome

\section{Methodology}

Testing for aCL. Both GPL and MPL were tested using commercially available enzyme-linked immunosorbent (ELISA) assay kits from Sanofi Diagnostics Pasteur Inc., USA (cat. No. 30969). The instructions provided by the manufacturer were followed in exact details. Results were expressed in GPL and MPL units for $\mathrm{IgG}$ and IgM isotypes of aCL, respectively.

Testing for Anti- $\beta_{2}-G P I$. Both the IgG as well as the IgM isotypes of anti- $\beta_{2}$-GPI were tested using commercially available ELISA kits from Varelisa, USA (cat. No. 19096 for the 'screening' including all the 3 major immunoglobulin isotypes; cat. No. 18796 for anti- $\beta_{2}-$ GPI of IgG isotype and cat. No. 18896 for IgM isotype). The instructions provided by the manufacturer were followed in exact details. Results were expressed in international units for IgG and IgM isotypes of anti$\beta_{2}$-GPI, respectively.

It is to be noted that these kits conform to the standards laid down in the international workshops on the determination of different aPL [5].

$L A C$ Methodology. The guidelines on testing for LAC as proposed by the SSC subcommittee for standardisation of LAC were followed for the detection of phospholipid-dependent inhibitors of blood coagulation [15]. These included kaolin clotting time or activated partial thromboplastin time with diluted plasma [16] and the diluted Russell viper venom time [17].

\section{Data Analysis}

The results were analysed using the Statistical Package for Social Sciences. The reliability of diagnostic tests was assessed using the diagnostic accuracy indices (sensitivity, specificity, positive and negative predictive values, and overall diagnostic accuracy). These indices reflect the extent of false-positive and false-negative results [18].

\section{Results and Observation}

\section{Patients}

The study included a total of 38 patients: 9 subjects in group 1, 17 in group 2 (10 in group $2 \mathrm{a}$ and 7 in group 2b) and 12 in group 3. The activated partial thromboplastin time result was not available for 1 patient from group 3 who had some features suggestive but not confirmatory of APS. Demographic details including median age, age 
Table 1. Demographic and clinical features of 38 patients included in the study

\begin{tabular}{|c|c|c|c|c|c|c|c|c|c|c|}
\hline \multirow{3}{*}{$\begin{array}{l}\text { Patient groups } \\
\text { Typical primary APS }(n=9)\end{array}$} & \multicolumn{2}{|c|}{ Age, years } & \multirow{2}{*}{$\begin{array}{l}\text { Gender } \\
\text { F:M }\end{array}$} & \multicolumn{7}{|c|}{ Clinical manifestations of APS } \\
\hline & \multirow{2}{*}{$\begin{array}{l}\text { median } \\
33.5\end{array}$} & \multirow{2}{*}{$\begin{array}{l}\text { range } \\
16-60\end{array}$} & & \multicolumn{2}{|c|}{$\begin{array}{l}\text { haema- DVT } \\
\text { tological }\end{array}$} & \multirow{2}{*}{$\begin{array}{l}\begin{array}{l}\text { recurrent } \\
\text { fetal loss }\end{array} \\
2\end{array}$} & \multirow{2}{*}{$\begin{array}{l}\begin{array}{l}\text { arterial } \\
\text { thrombosis }\end{array} \\
1 \\
\end{array}$} & \multirow{2}{*}{$\begin{array}{l}\text { CNS } \\
3\end{array}$} & \multirow{2}{*}{$\begin{array}{l}\text { VHD } \\
\text { nil }\end{array}$} & \multirow{2}{*}{$\begin{array}{l}\text { CAPS } \\
1\end{array}$} \\
\hline & & & $7: 2$ & 4 & 1 & & & & & \\
\hline System & $=17)$ & & & & & & & & & \\
\hline With secondary APS $(n=10)$ & 27.5 & $20-40$ & $17: 0$ & 5 & 0 & 0 & 1 & 3 & 1 & 5 \\
\hline Without secondary APS $(n=7)$ & 38 & $17-56$ & 5 & nil & nil & nil & nil & nil & nil & nil \\
\hline $\begin{array}{l}\text { Miscellaneous group with weak } \\
\text { evidence of APS }(n=12)\end{array}$ & 33.5 & $21-50$ & $8: 4$ & 2 & 3 & nil & 3 & 4 & nil & nil \\
\hline
\end{tabular}

Haematological manifestations = Auto-immune haemolytic anaemia/thrombocytopenia; DVT = deep-vein thrombosis; CNS manifestations = cerebrovascular accidents/headaches; VHD = valvular heart disease; CAPS = catastrophic APS.

Table 2. Correlation of different tests for aPL with clinical manifestations of APS

\begin{tabular}{|c|c|c|c|c|c|c|c|c|c|c|}
\hline & \multicolumn{2}{|l|}{ APTT $^{1}$} & \multicolumn{2}{|c|}{$\mathrm{GPL}^{2}$} & \multicolumn{2}{|c|}{$\mathrm{MPL}^{3}$} & \multicolumn{2}{|c|}{$\begin{array}{l}\text { Anti- } \beta_{2} \text {-GPI- } \\
\text { GPL }(\operatorname{IgG})^{4}\end{array}$} & \multicolumn{2}{|c|}{$\begin{array}{l}\text { Anti- } \beta_{2} \text {-GPI- } \\
\text { MPL }(\mathrm{IgM})^{5}\end{array}$} \\
\hline & prolonged & normal & + & - & + & - & + & - & + & - \\
\hline APS present & 5 & 13 & 15 & 4 & 7 & 12 & 7 & 12 & 5 & 14 \\
\hline APS not present & 1 & 18 & 7 & 12 & 2 & 17 & 0 & 19 & 2 & 17 \\
\hline Sensitivity, $\%$ & \multicolumn{2}{|l|}{27.8} & \multicolumn{2}{|c|}{78.9} & \multicolumn{2}{|c|}{36.8} & \multicolumn{2}{|c|}{36.8} & \multicolumn{2}{|c|}{26.3} \\
\hline Specificity, \% & \multicolumn{2}{|l|}{94.7} & \multicolumn{2}{|c|}{63.2} & \multicolumn{2}{|c|}{89.5} & \multicolumn{2}{|c|}{100.0} & \multicolumn{2}{|c|}{89.5} \\
\hline PPV, \% & \multicolumn{2}{|l|}{83.3} & \multicolumn{2}{|c|}{68.2} & \multicolumn{2}{|c|}{77.8} & \multicolumn{2}{|c|}{100.0} & \multicolumn{2}{|c|}{71.4} \\
\hline NPV, $\%$ & \multicolumn{2}{|l|}{58.1} & \multicolumn{2}{|c|}{75.0} & \multicolumn{2}{|c|}{58.6} & \multicolumn{2}{|c|}{61.3} & \multicolumn{2}{|c|}{54.8} \\
\hline $\mathrm{DA}, \%$ & \multicolumn{2}{|l|}{60.5} & \multicolumn{2}{|c|}{71.1} & \multicolumn{2}{|c|}{63.2} & \multicolumn{2}{|c|}{68.4} & \multicolumn{2}{|c|}{57.9} \\
\hline
\end{tabular}

$\mathrm{PPV}=$ Positive predictive value $\mathrm{NPV}=$ negative predictive value; $\mathrm{DA}=$ diagnostic accuracy.

1 Activated partial thromboplastin time as a surrogate for LAC.

2 Anticardiolipin antibody of IgG isotype, in GPL units; considered negative if $\leq 23$ GPL units.

3 Anticardiolipin antibody of IgM isotype, in MPL units; considered negative if $\leq 11$ MPL units.

4 Anti- $\beta_{2}$-GPI of IgG isotype, in international units; considered negative if $\leq 10$ units.

5 Anti- $\beta_{2}$-GPI of IgM isotype, in international units; considered negative if $\leq 10$ units.

range, female-to-male ratio and clinical features pertinent to subjects with primary and secondary APS are given in table 1 . Of the 12 subjects in the miscellaneous category (group 3, i.e. those with clinically 'weak' evidence for APS) the diagnoses were demyeli- nating diseases of the central nervous system (2 patients), transverse myelitis (1 patient), cerebrovascular accident in a young woman (1 patient), systemic necrotising vasculitis (2 patients), cutaneous vasculitic syndrome (1 patient), syndrome of haemolytic anaemia 
with elevated liver enzymes and low platelets (1 patient), Sjögren's syndrome with anemia suspected to be haemolytic (1 patient), chronic inflammatory arthritides with deep venous thrombosis ( 2 patients) and Behcet's disease with deep-vein thrombosis (1 patient). As can be appreciated, each of these patients had at least one clinical feature at the outset that could be considered a manifestation of APS. However, the subsequent course and investigations pointed out alternative diagnoses other than APS.

Analysis of the Results on aPL Estimations The analysis of the results is given in table 2 . As can be seen, the highest sensitivity and diagnostic accuracy were obtained by the estimation of GPL, i.e. 78.9 and $71.1 \%$, respectively. However, the specificity and positive predictive value were relatively lower than those of other tests (63.2 and 68.2\%, respectively). The highest specificity and positive predictive value were observed with the estimation of anti- $\beta_{2}$-GPI of IgG isotype. All the other tests performed poorly when compared with these 2 tests.

\section{Discussion}

Despite the availability of a number of laboratory tests for the screening of aPL, several workers have emphasised the difficulties in the interpretation of their clinical relevance/ significance $[2,5,19-27]$. These and other studies, however, appear to reach a consensus that although generally GPL and LAC show a good correlation among themselves and with the thrombotic manifestations of APS, mainly thrombosis, LAC correlates much more with venous thrombosis [27, 28]. Some studies have shown a correlation of the IgA isotype of aCL with thrombocytopenia [29] while the IgM isotype of aCL has been shown to corre- late with auto-immune haemolytic anaemia [30]. Some studies have suggested that aCL correlates better with recurrent fetal wastage, LAC correlates better with thrombotic events [31-33]. The present study showed a good correlation between GPL and LAC (Spearman correlation coefficient 0.6258, 2-tailed significance 0.000 ), and their good correlation with clinical manifestations of APS. This finding is in agreement with some of the earlier studies [31-33]. Although LAC showed a high positive predictive value for the presence of clinical features of APS, it was less sensitive in comparison with the IgG isotype of aCL. The present study also showed the highest clinical accuracy of GPL that is in agreement with several earlier studies [28, 30, 34-36].

In recent years a large number of studies have shown a high positive predictive value of anti- $\beta_{2}$-GPI for APS [19, 36-42]. The present study showed that of the various aPL available GPL closely followed by the $\operatorname{IgG}$ isotype of anti- $\beta_{2}$-GPI has the highest diagnostic accuracy. Other aPL also performed well but did not reach the same high levels of diagnostic accuracy. However, a look at the results would make it obvious that patients with clinically definite APS may have any one but not always both of these antibodies. Therefore, in practical terms, it may be necessary to carry out the tests for both of these antibodies in clinical situations where APS is a clinical possibility. However, it could be recommended that until more specific and more sensitive diagnostic test(s) become(s) available for the laboratory confirmation of APS, it would be prudent to screen for the presence of IgG isotypes of both aCL as well as anti- $\beta_{2}$-GPI. Possibly this would provide a highly satisfactory level of diagnostic accuracy. Other workers have found mainly the IgG isotype of anti- $\beta_{2^{-}}$ GPI to be more accurate for the clinical diagnosis of APS than GPL $[19,37,40]$. The difference between the clinical accuracies of 
these 2 antibodies was only marginal in the present study. It is therefore possible that in a large series anti- $\beta_{2}$-GPI may show higher clinical accuracy.

It is to be noted that the field of detection of 'pathogenic' versus 'non-pathogenic' aPL is still wide open with a number of additional antibodies being claimed as the 'true' marker of the clinical APS [25, 43, 44]. It would probably require much more observation and many more studies to reach the final conclusion regarding this perplexing issue. In the meantime, guidelines provided by Stratta et al. [45] may be found extremely helpful in situations where discrepancy is noted between the clinical setting and the laboratory results.

\section{Ackowledgments}

The authors are obliged to Ms. Samar Abdul Majeed, Ms. Loraine D’Souza, Mrs. Sicy K. Easow and Dr. Mini Abraham for their technical help. We are also grateful to our clinical colleagues for their co-operation.

\section{References}

1 Hughes GVR: Thrombosis, abortion, cerebral disease and lupus anticoagulant. Br Med J 1983;287: 1088-1089

2 Bick RL, Baker WF: The antiphospholipid and thrombosis syndromes. Med Clin North Am 1994; 78:667-684.

3 Harris EN, Baguely E, Asherson RA, Hughes GRV: Clinical and serological features of the antiphospholipid syndrome (Hughes syndrome) (abstract). $\mathrm{Br} \mathrm{J}$ Rheumatol 1987; 26(suppl 2): 19.

4 Khamashta MA, Asherson RA: Hughes syndrome: Antiphospholipid antibodies move closer to thrombosis in 1994. Br J Rheumatol 1995;34:493-494.

5 Conference recommendation. Sixth International Symposium on Antiphospholipid Antibodies - Leuven, Belgium, 14-17 September 1994 Abstracts. Lupus 1994;3:313-364.

6 Malaviya AN, Marouf R, Al-Jarallah K, Al-Awadi A, Al-Saied K, AlGaurer S, Khamis A, Al-Salem I, Raghupathy R, Al-Mazidi M, Serebour F, Umamaheswaran I, Mourou M, Mokhtar M, Qurtom M, Raoof Al-Shayeb A, Taresevicius T, Hussain MA: Hughes syndrome: A common problem in Kuwait hospitals. Br J Rheumatol 1996;35:11321136.
7 Asheron RA, Cervera R, Lie JT: The antiphospholipid syndromes; in Lahita RG (ed): Systemic Lupus erythematosus, ed 3. Boston, Academic Press, 1999, pp 829-870.

8 Alarcon-Segovia D: Clinical manifestations of the antiphospholipid syndrome. J Rheumatol 1992;19: 1778-1781.

9 Alarcon-Segovia D, Cabral AR: The antiphospholipid/cofactor syndromes. J Rheumatol 1996;23: 1319-1322.

10 Khamashta MA, Hughes GVR: Antiphospholipid antibodies and antiphospholipid syndrome. Curr Opin Rheumatol 1995;7:389-394.

11 Pierangeli SS, Stewart M, Silva LK, Harris EN: An antiphospholipid wet workshop: 7th International Symposium on Antiphospholipid Antibodies. J Rheumatol 1998;25:156160.

12 Asherson RA, Khamashta MA, Ordi-Ros J, Derksen RH, Machin SJ, Barquinero J, Outt HH, Harris EN, Vilardell-Torres M, Hughes GR: The 'primary' antiphospholipid syndrome: Major clinical and serological features. Medicine (Baltimore) 1989;68:366-374.

13 Alarcon-Segovia D, Perez-Vazquez ME, Villa AR, Drenkard C, Cabiedes $\mathrm{J}$ : Preliminary classification criteria for the antiphospholipid syndrome within systemic lupus erythematosus. Semin Arthritis Rheum 1992;21:275-286.
14 Asherson RA, Cervera R, Piette J, Shoenfeld Y: The antiphospolipid syndrome: History, definition, classification, and differential diagnosis; in Asherson RA, Cervera R, Piette J, Schoenfeld Y (eds): The Antiphospholipid Syndrome. Boca Raton, CRC Press, 1996, pp 3-28.

15 Exner T, Triplett DA, Taberner D, Machin J: Guidelines for testing and revised criteria for lupus anticoaglants. SSC Subcommittee in standardisation of lupus anticoagulants. Thromb Haemost 191;65:320-322.

16 Exner T, Rickard KA, Kronenberg $\mathrm{H}$ : A sensitive test for demonstrating lupus anticoagulant and its behavioural pattern. $\mathrm{Br} \mathrm{J}$ Haematol 1978;40:143-148.

17 Thiagarajan P, Pengo V, Shapiro SS: The use of the dilute Russell viper venom time for the diagnosis of lupus anticoagulants. Blood 1986;68: 869-874.

18 Armitage P, Berry G: Statistical Methods in Medical Research. Oxford, Blackwell Scientific Publications, 1991, pp 472-475.

19 Day HM, Thiagarajan P, Ahn C, Reveille JD, Tinker KF, Arnett FC: Antibodies to anti- $\beta_{2}$-glycoprotein-I in systemic lupus erythematosus and primary antiphospholipid antibody syndrome: Clinical correlations in comparison with other antiphospholipid antibody tests. J Rheumatol 1998;25:667-674.

Kaushik/Malaviya/Al-Attiya/Moussa/ Das 
20 Johns AS, Chamley L, Ockelford PA, Pattison NS, McKay EJ, Corkill M, Hart H: Comparison of tests for the lupus anticoagulant and antiphospholipid antibodies in systemic lupus erythematosus. Clin Exp Rheumatol 1994;12:523-526.

21 Lockshin MD: Antiphospholipid antibody syndrome. Rheum Dis Clin North Am 1994;20:45-59.

22 Khamashta MA, Hughes GRV: Antiphospholipid antibodies and antiphospholipid syndrome. Curr Opin Rheumatol 1995;7:389-394.

23 Mackworthyoung CG: Antiphospholipid antibodies and disease. $\mathrm{Br}$ J Rheumatol 1995;34:1009-1030.

24 Devine DV, Bridgen ML: The antiphospholipid syndrome: When does the presence of antiphospholipid antibodies require therapy? Postgrad Med 1996;99:105-108, 113-125.

25 Sammaritano LR, Ng S, Sobel R, Lo SK, Simantov R, Furie R, Kaell A, Silverstein R, Salmon JE: Anticardiolipin IgG subclasses: Association of $\mathrm{IgG} 2$ with arterial and/or venous thrombosis. Arthritis Rheum 1997; 40:1998-2006

26 Wahl DG, Guillemin F, Demaistre E, Perret C, Lecompte T, Thibaut G: Risk for venous thrombosis related to antiphospholipid antibodies in systemic lupus erythematosus - A meta-analysis. Lupus 1997;6:467473.

27 Wahl DG, Guillemin F, Demaistre E, Perretguillaume C, Lecompte T, Thibaut G: Meta-analysis of the risk of venous thrombosis in individuals with antiphospholipid antibodies without underlying autoimmune disease or previous thrombosis. Lupus 1998;7:15-22.

28 Verro P, Levine SR, Tietjen GE: Cerebrovascular ischemic events with high positive anticardiolipin antibodies. Stroke 1998;29:2245-2253.

29 Lopez LR, Santos ME, Espinoza LR, La Rosa FG: Clinical significance of immunogloublin A versus immunoglobulins $\mathrm{G}$ and $\mathrm{M}$ anti-cardiolipin antibodies in patients with systemic lupus erythematosus: Correlations with thrombosis, thrombocytopenia, and recurrent abortion. Am J Clin Pathol 1992;98:449-454.
30 Lopez-Soto A, Cervera R, Font J, Bove A, Reverter JC, Munoz FJ, Miret C: Isotype distribution and clinical significance of antibodies to cardiolipin, phosphatidic acid, phosphatidylinositol and phosphatidylserine in systemic lupus erythematosus: Prospective analysis of a series of 92 patients. Clin Exp Rheumatol 1997;15:143-149.

31 Lockshin MD, Qamar T, Druzin ML: Comparison of antibody to cardiolipin and activated partial thromboplastin time as predictors of fetal death in pregnant patients with systemic lupus erythematosus. J Rheumatol 1987;14:259-262.

32 McHugh NJ, Moye DAH, James IE, Sampson M, Maddison PJ: Lupus anticoagulant - Clinical significance in anticardiolipin positive patients with systemic lupus erythematosus. Ann Rheum Dis 1991;50:548-552.

33 Long AA, Ginsberg JS, Brill-Edwards $\mathrm{P}$, Johnston $\mathrm{M}$, Turner $\mathrm{C}$, Denburg JA, Bensen WG, Cividino A, Andrew M, Hirsh J: The relationship of antiphospholipid antibodies to thromboembolic disease in systemic lupus erythematosus - A cross-sectional study. Thromb Haemost 1991;66:520-524.

34 Aoki K, Dudkiewicz AB, Matsuura E, Novotny M, Kaberlein G, Gleicher N: Clinical significance of beta 2glycoprotein I-dependent anticardiolipin antibodies in the reproductive autoimmune failure syndrome: Correlation with conventional antiphospholipid antibody detection systems. Am J Obstet Gynecol 1995; 172:926-931.

35 Melk A, Mueller-Eckhardt G, Polten B, Lattermann A, Heine O, Hoffmann O: Diagnostic and prognostic significance of anticardiolipin antibodies in patients with recurrent spontaneous abortions. Am J Reprod Immunol 1995;33:228-233.

36 Martinuzzo ME, Forastiero RR, Carreras LO: Anti-beta-2-glycoprotein I antibodies: Detection and association with thrombosis. Br J Haematol 1995;89:397-402.
37 Koike T, Matsuura E. Anti- $\beta_{2}$-glycoprotein-I antibody: Specificity and clinical significance. Lupus 1996;5: 378-380.

38 Navarro M, Cervera R, Teixido M, Reverter JC, Font J, Lopez-Soto A, Monteagudo J, Escolar G, Ingelmo M: Antibodies to endothelial cells and to beta-2-glycoprotein I in the antiphospholipid syndrome: Prevalence and isotype distribution. $\mathrm{Br} \mathrm{J}$ Rheumatol 1996;35:523-528.

39 Puurunen M, Vaarala O, Julkunen $\mathrm{H}$, Aho K, Palosuo T: Antibodies to phospholipid-binding plasma proteins and occurrence of thrombosis in patients with systemic lupus erythematosus. Clin Immunol Immunopathol 1996;80:16-22.

40 Tsutsumi A, Matsuura E, Ichikawa K, Fujisaku A, Mukai M, Kobayashi S, Koike T: Antibodies to beta-2-glycoprotein I and clinical manifestations in patients with systemic lupus erythematosus. Arthritis Rheum 1996;39:1466-1474.

41 Alarcon-Segovia D, Mestanza M, Cabiedes J, Cabral AR: The antiphospholipid/cofactor syndromes. 2. A variant in patients with systemic lupus erythematosus with antibodies to beta(2)-glycoprotein I but no antibodies detectable in standard antiphospholipid assays. J Rheumatol 1997;24:1545-1551.

42 Fanopoulos D, Teodorescu MR, Varga J, Teodorescu M: High frequency of abnormal levels of IgA anti-beta(2)-glycoprotein I antibodies in patients with systemic lupus erythematosus: Relationship with antiphospholipid syndrome. J Rheumatol 1998;25:675-680.

43 Galli M: Non- $\beta_{2}-\mathrm{GP}-1$ cofactors for antiphosholipid antibodies. Lupus 1996;5:388-392.

44 Puurunen M, Vaarala O, Julkunen $\mathrm{H}$, Aho K, Palosuo T: Antibodies to phospholipid-binding plasma proteins and occurrence of thrombosis in patients with systemic lupus erythematosus. Clin Immunol Immunopathol 1996;80:16-22.

45 Stratta P, Canavese C, Ferrero S, Grill A, Piccoli G: Guidelines for looking at the antiphospholipid antibodies in systemic lupus erythematosus. Nephron 1997; 76:400-405. 